\title{
MANDATORY CORPORATE SOCIAL RESPONSIBILITY IN INDONESIA
}

\section{Laurensia Andrini*}

\author{
Business Law Department, Faculty of Law Universitas Gadjah Mada, Yogyakarta \\ Jalan Sosio Yustisia Nomor 1 Bulaksumur, Sleman DI Yogyakarta 55281
}

\section{Abstract}

Regulation on Corporate Social Responsibility (CSR) under laws and regulations of Limited Liability Company have not given clarity and legal certainty as it does not stipulate sanction and control mechanism. In the practical level, the implementation of CSR is often mistargeted because the company does not have a clear guidance to fulfill people's demand. It is the purpose of this article to elaborate how far CSR is obligatory towards Limited Liability Companies who perform business in the field of and or related to natural resources as well as to understand the reason behind mandatory CSR in Indonesia.

Key words: responsibility, social, mandatory, corporate.

\section{Intisari}

Peraturan mengenai Tanggung Jawab Sosial dan Lingkungan yang diatur dalam peraturan perundangundangan mengenai Undang-undang Perseroan Terbatas belum memberikan kejelasan dan kepastian hukum karena tidak adanya sanksi dan mekanisme pengawasan. Dalam ranah praktis, penerapan TJSL seringkali kurang tepat sasaran karena Perseroan Terbatas tidak memiliki panduan yang jelas untuk memenuhi permintaan masyarakat. Penelitian ini ditujukan untuk memahami sejauh mana kewajiban TJSL terhadap Perseroan Terbatas yang melakukan usaha di bidang atau terkait dengan sumber daya alam, sekaligus untuk memahami alasan di balik kewajiban TJSL di Indonesia.

Kata Kunci: tanggung, jawab, sosial, kewajiban, perusahaan.

\section{Pokok Muatan}

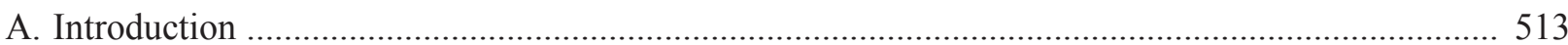

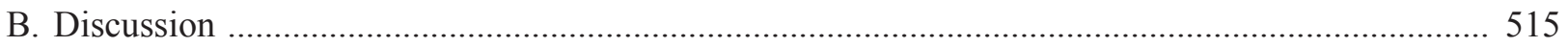

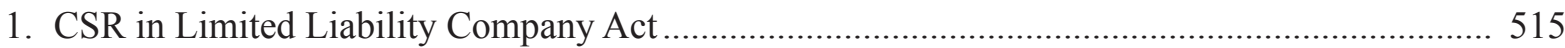

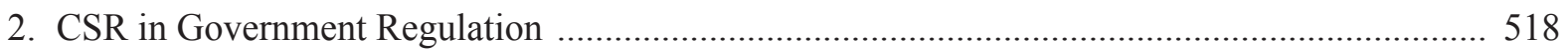

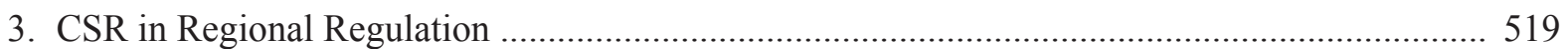

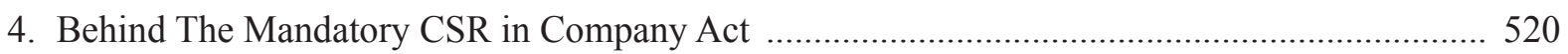

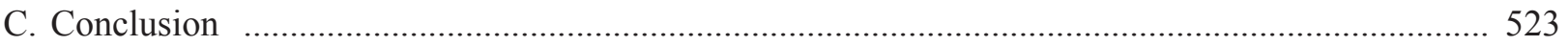




\section{A. Introduction}

The idea of Corporate Social Responsibility (CSR) emerges in the 1990s as a self-regulation and voluntary initiatives of a corporation. ${ }^{1}$ It is trying to achieve sustainable development, which is seeking to meet the needs of the present without compromising the ability of future generation to meet their own needs. ${ }^{2}$ Gladwin and Kennelly define sustainable development as a process of achieving human development in an inclusive, connected, equiparable, prudent, and secure manner. ${ }^{3}$ With regards to CSR, company is obliged to do something to the society in order to maintain a sustainable development.

The scope of CSR may vary, ranging from the company's code of conduct, environmental concern, community service, as well as improvement of health and safety. In Indonesia, the CSR for limited liability company (company) has been turned into an obligation since the enacment of Act No. 40 of 2007 regarding Limited Liability Company (Company Act). In this act, CSR becomes the obligation of the company at its own cost. ${ }^{4}$ Furthermore, when a company cannot fulfill the CSR obligation, it would be given sanction. ${ }^{5}$

Regulating CSR in Indonesia as company's obligation is somehow not in line with the very first purpose of the CSR itself. In European countries, for example, CSR is considered as voluntary business contribution to the sustainable development. Furthermore, it is also seen as active corporate engagement that goes beyond legal compliance. ${ }^{6}$ As compared to Indonesia, after the establishment of Company Act and its implementing regulations, the CSR cannot be seen as voluntary contribution to the people anymore. Neither can it be seen as the corporate engagement outside of the legal regulation. Instead, it is performed in order to fulfill the legal obligation.

The establishment of CSR's obligatory nature in Indonesia faces much objection, mainly from the private sectors (company). Indonesia Chamber of Commerce and Industry together with some associations and companies have ever submitted judicial review to the Constitutional Court of Indonesia. They wanted to challenge Art. 74 of the Company Act which requires mandatory CSR. Eventually, the Constitutional Court rejected the judicial review and strengthening the obligatory nature of CSR for the company in Indonesia. One of the bases used by Constitutional Court is the people oriented economy, which is in line with the Art. 33 paragraph (4) of the Indonesian Constitution. Even though the judicial review has been rejected by the Constitutional Court, the debates on whether the CSR shall be mandatory or voluntary in nature goes on. The debate does not only affect the mind of legal scholars, but also results in blurred CSR program implementation. ${ }^{7}$

Company Act uses Corporate Environmental and Social Environment (CESR) instead of CSR to impose obligation towards the company. It is further elaborated by government in the Constitutional Court forum that the concept of CESR and CSR is different in three regards, namely the regulation, funding, and sanction. According to the regulation, CESR is only obligatory to the limited liability company who conduct business in the field of and/

United Nations Research Institute for Social Development, "Research and Policy Brief 1 Corporate Social Responsibility and Business Regulation", http://www.unrisd.org/80256B3C005BCCF9/httpNetITFramePDF?ReadForm\&parentunid=F862A71428FAC633C1256E9B0 $02 F 1021$ \& parentdoctype $=$ brief\&netitpath $=80256$ B3C005BCCF9/(httpAuxPages) $/$ F862A71428FAC633C1256E9B002F1021/\$file/RPB1e $p d f$, accessed on 2 Februari 2016.

World Commission on Environmental and Development, 1987, Our Common Future, Oxford University Press, Oxford, p. 8.

Thomas Gladwin and James Kennelly, "Shifting Paradigm for Sustainable Development: Implications for Management Theory and Research", Academy of Management Review, Vol. 20, No. 4, 1995, pp. 874-904.

Art. 74 (2) of Act No. 40 of 2007 regarding Limited Liability Company ( State Gazette of The Republic of Indonesia Year 2007 Number 106 , Supplement to State Gazette of The Republic of Indonesia Number 4756.

Art. 74(3) of Act No. 40 of 2007 regarding Limited Liability Company ( State Gazette of The Republic of Indonesia Year 2007 Number 106, Supplement to State Gazette of The Republic of Indonesia Number 4756.

$6 \quad$ European.Sustainable.Development.Network, 2011, Focus CSR: The New Communication of the EU Commission on CSR and National CSR Strategies and Action Plans, ESDN Quarterly Report, European.Sustainable.Development.Network, Viena, p.7.

Sabela Gayo, "Mandatory and Voluntary Corporate Social Responsibility Policy Debates in Indonesia", ICIRD, June, 2012 , p. 2. 
or related to natural resources; meanwhile CSR is obligatory towards all limited liability company. The funding of CESR is burdened upon company's operational cost, meanwhile CSR funding is taken from company's nett profit. Last but not least, sanction in accordance with sectoral law is imposed towards breach to CESR, but there is only moral sanction imposed to those who do not perform $\mathrm{CSR}^{8}$

Government's elaboration on the differences between CSR and CESR is, however, ridiculous as it also lacks of legal bases. It can be seen from the first difference of CSR and CESR in which government argues that CSR is obligatory for all limited liability company, ${ }^{9}$ despite which business they perform. In fact, the Company Act has not ever regulated such matter. Obligatory $\mathrm{C}(\mathrm{E}) \mathrm{SR}$ is only imposed to those having business in the field of and/or related to natural resources. There is no stipulation of other type of contribution (such as CSR) which becomes obligatory to all companies.

Using word 'environment' to differ CSR and CESR is also redundant. ${ }^{10}$ Dictionary of American Heritage defines environment as the complex of social and cultural conditions affecting the nature of an individual person or community. It can also be understood as the totality of the natural world, including person, animal, or plant. ${ }^{11}$ From the definition, it can be inferred that environment generally means everything in the universe, and not only limited to natural environment as might have been preferred by the government in its Company Act.

Constitutional Court, in its decision No. 53/ PUU-VI/2008 uses CESR and CSR interchangeably. It also shows that government's argument on the difference of CESR and CSR has no significant contribution towards Constitutional Court's view on CSR. Therefore, CESR and CSR in this article shall refer to one another and be used interchangeably.

In terms of CSR regulation itself, there is no clear regulation on the obligation of each company related to CSR. In the Company Act, for example, the company having activities in natural resources have social and environmental responsibility. ${ }^{12}$ Further regulation for limited liability company is mentioned in the Government Regulation No. 47 of 2012 on the Social and Environmental Responsibility of Limited Liability Company. This implementing regulation does not give much clue on what the corporate shall do when fulfilling the CSR requirement. On one side, it gives freedom towards the company to do fulfill the CSR obligation. Nonetheless, it may also divert the purpose of CSR itself since the company engagement is not directed towards affected group of people. ${ }^{13}$

In the author's view, government has a mediocre stance in regulating CSR in Indonesia. In one hand, it wants to create social and environmental obligation towards limited liability company having business related to the utilization of natural resources. But on the other hand, government seems to leave the obligation to the company without any specific regulation on how should the company perform its CSR. It can be best understood that the government wants to oblige the company without giving too much force and pressure into it. This mediocre stance, however, gives space to the company to perform any kind of CSR at its own costs without considering the core purpose of CSR, i.e. to give back what has been taken from the people. Then again, it's the people who will be suffering due to the company's activities.

Main problems identified in this study are

\footnotetext{
Constitutional Court Decision No. 53/PUU-VI/2008.

Ibid.

Laurensia Andrini, 2016, Corporate Social Responsibility for Limited Liability Company in Indonesia as a Mechanism to Improve People's Welfare, Graduate Thesis, Faculty of Law Universitas Gadjah Mada, Yogyakarta.

11 The American Heritage Dictionary, "What is Environment", https://www.ahdictionary.com/word/search.html? q=environment, accessed on 2 February 2016.

12 Art..74(1) of Act No. 40 of 2007 regarding Limited Liability Company ( State Gazette of The Republic of Indonesia Year 2007 Number 106, Supplement to State Gazette of The Republic of Indonesia Number 4756.

13 Affected group of people, in this regard is those who receive consequences due to the company's business in the field or related to the natural
} resources. 
First, how mandatory CSR is for limited liability company having business in the field of and/or related to natural resources, and Second, why CSR needs to be mandatory instead of voluntary.

\section{B. Discussion}

\section{CSR in Limited Liability Company Act}

Indonesian Company Act requires a mandatory CSR for the company having activities in the field of and/or related to natural resources. ${ }^{14}$ Company doing business in the field of natural resources is defined as the company whose activities is to manage and utilize natural resources. ${ }^{15}$ Meanwhile company whose business is related to natural resources is defined as the company who does neither manage nor utilize natural resources; nonetheless, its business operation affects the function of natural resources. ${ }^{16}$

As a mandatory conduct, company who does not perform CSR will be given sanction in accordance to laws and regulations. ${ }^{17}$ Unfortunately, the Company Act as well as Government Regulation on CSR do not regulate the kind of sanction which will be imposed to the companies who have no CSR. In theoretical level, this leaves a law with no sanction, or lex imperfecta. The law is considered incomplete because it lacks of sanction. ${ }^{18}$ For some legal scholars, the existence of sanction is important in order to discourage individual, or company in this regard, to avoid act forbidden by the law. ${ }^{19}$ When it comes to the mandatory CSR, the stipulation of sanction is necessary so that the company is encouraged to perform its obligation and try its best to avoid sanctions.
Within the development of legal science, the lack of sanction is no longer considered as a failure anymore. On the contrary, it might show a successful role of law within the society. ${ }^{20}$ This can only happen in a very ideal condition where the company is so considerate that its motivation is to bring welfare to the people, and not merely to avoid sanction. In this ideal scheme of society, lex imperfecta is not imperfect anymore. Instead, it shows a good sign of the society's development. The hypothetical condition shows that sanction is needed to regulate the disordered society; while it might not be needed anymore when the society has already been in order. Therefore, it is necessary to consider the circumstances when law was created.

There are at least two objectives behind the establishment of the present Company Act, i.e. to create a strong economic organization in creating people's welfare ${ }^{21}$ and to create a conducive business atmosphere in Indonesia. ${ }^{22}$ Those objectives may sometimes contradict each other at its application. It requires government's role to create the law which is able to walk between the interests of both businessman and the people. The Company Act tries to create a balance in fulfilling people's needs and business sector's demand. In terms of CSR, it obliges certain company to contribute something towards people's interests. Failing to do so, the company is subject to a particular sanction which has not been regulated any further by either the law or its implementing regulations.

It is important to understand that the objectives of Company Act is not only to protect people's interests. It is also aimed to create a conducive busi-

\footnotetext{
14 Art. 74(1) of Act No. 40 of 2007 regarding Limited Liability Company ( State Gazette of The Republic of Indonesia Year 2007 Number 106 , Supplement to State Gazette of The Republic of Indonesia Number 4756.

5 Elucidation of Act No. 40 of 2007 regarding Limited Liability Company ( State Gazette of The Republic of Indonesia Year 2007 Number 106 , Supplement to State Gazette of The Republic of Indonesia Number 4756.

6 Ibid.

17 Art. 74(3) of Act No. 40 of 2007 regarding Limited Liability Company ( State Gazette of The Republic of Indonesia Year 2007 Number 106, Supplement to State Gazette of The Republic of Indonesia Number 4756.

Thomas A. J. McGinn, "The Expressive Function of Law and Lex Imperfecta”, Roman Legal Tradition, Vol. 11, 2015, pp. 1-41. Ibid.

Point a Considerations of Act No. 40 of 2007 regarding Limited Liability Company (State Gazette of The Republic of Indonesia Year 2007 Number 106, Supplement to State Gazette of The Republic of Indonesia Number 4756.

22 Point b of Act No. 40 of 2007 regarding Limited Liability Company (State Gazette of The Republic of Indonesia Year 2007 Number 106, Supplement to State Gazette of The Republic of Indonesia Number 4756.
} 
ness atmosphere. A mention of sanction in the Act or its implementing regulations will highly likely discourage people from establishing business. ${ }^{23}$ Even without a clear sanction stipulated in the laws and regulations, businessmen seem to be unhappy with the mandatory CSR obligation. It is shown by the judicial review submitted to the Constitutional Court by Indonesia Chamber of Commerce and Industry together with some associations and companies. They proposed review on Art. 74 of Company Act which requires that CSR shall be mandatory because they thought that it was discriminatory and uncertain on at least three grounds: ${ }^{24}$

a. The stipulations of CSR is in contradiction with the CSR's voluntary nature (beyond legal compliance);

b. CSR will not only affect higher cost on business operation, but it can also be considered as double collection other than tax;

c. CSR cannot reach the already-targeted goal as it can highly likely be misused by the authority, especially because it imposes sanction.

This action shows that most businessmen want CSR to be voluntarily applied. As a result, the sanction towards those who do not perform CSR will also be unreasonable as it is not a binding obligation. This fact may also be the background why there is no clear sanction mentioned in the Company Act.

Indonesian Constitutional Court is in the view that there is sanction imposed to the companies who do not perform CSR obligation. It implies that the sanction has been regulated under other sectoral law.
[...] TJSL/CSR secara implisit telah diatur dalam peraturan perundang-undangan (sektoral) yang lainnya, seperti antara lain: Undang-undang Kehutanan, Undang-undang Lingkungan Hidup, dan Undang-undang Sumber daya Air serta Undang-undang tentang Minyak dan Gas Bumi $[\ldots] .{ }^{25}$

When obligation on CSR is linked to other laws; it means that such obligation is not unguided. Instead, company has a great deal of obligations in accordance to such sectoral law, for example Law on Forestries, Environment Act, Law on Water Resources, as well as Law on Oil and Gas. In the environmental sector, for example, business who have impact to the environment shall obtain environmental permit. ${ }^{26}$ This permit will only be granted after business entity is considered as environmentally feasible by the authority. ${ }^{27}$ It contains requirements and obligations as mentioned in the Environmental Feasibility Decision or UKLUPL recommendation, additional requirements and obligations set by regional authority and the expiration date of such permit. ${ }^{28}$ If the company does not perform the requirements and obligations as regulated on its environmental permit, it will be subject to administrative sanction in the form of i) written notice; ii) coercion; iii) suspension of environment permit; or iv) revocation of environment permit. ${ }^{29}$

Towards the above-mentioned Constitutional Court's decision, the author has two point of arguments aimed to scrutinize majority of judges' rule on obligation and sanction contained in the sectoral law.

\section{a. Determining Corporate Social Responsibility}

The sectoral law does stipulate

\footnotetext{
This assertion was brought in the parliament's debate during the drafting of Limited Liability Company Act in 2007.

Constitutional Court Decision No. 53/PUU-VI/2008.

Ibid.

Art. 36(1) of Act No. 32 of 2009 on the Protection and Management of Environment (State Gazette of The Republic of Indonesia Year 2009 Number 140, Supplement to State Gazette of The Republic of Indonesia Number 5059).

27 Art. 36(2) of Act No. 32 of 2009 on the Protection and Management of Environment (State Gazette of The Republic of Indonesia Year 2009 Number 140, Supplement to State Gazette of The Republic of Indonesia Number 5059).

28 Art. 48(1) Government Regulation No. 27 of 2012 on Environmental Permit (State Gazette of The Republic of Indonesia Year 2012 Number 48, Supplement to State Gazette of The Republic of Indonesia Number 5285).

29 Art. 79 of Act No. 32 of 2009 on the Protection and Management of Environment (State Gazette of The Republic of Indonesia Year 2009 Number 140, Supplement to State Gazette of The Republic of Indonesia Number 5059).
} 
that the obligation shall be performed by an individual or company who performs business. However, it is not mentioned in thesaid law that such environmental obligation also belongs to CSR. In this regard, it is hard for the company to distinguish whether it has performed mandatory CSR as required by the Company Act or it has simply fulfill stipulation as required by other law.

In the practical level, it can be the case that the company has fulfilled the stipulation of Environment Act and therefore consider itself has performed the CSR obligation. Meanwhile, the nature of CSR, as asserted by Johnson and Scholes is the conduct in the way an organization exceeds minimum obligations specified through regulation and corporate governance. ${ }^{30}$ Meaning that a corporation that only meets legal requirements shall not be considered as having fulfilled the CSR as the conduct is merely obeying the law and not exceeding minimum obligations.

There is always a room for debate between the CSR which is meant to fulfill certain laws and regulations as suggested by the Constitutional Court judges; and the CSR which shall exceed minimum obligations. Towards this matter, the author is in the view of the latter, in which a company shall be considered of having performed CSR if it has performed something exceeding the stipulation in the laws and regulations.

Following the notion that CSR has to be performed exceeding the stipulation of laws and regulations, this present article is in contrast to Azheri's as the latter considers fulfilling legal obligation is also part of CSR. Azheri considers that the mandatory nature of CSR can be seen in the requirements for mining permit and environmental permit. ${ }^{31}$

The author supports Johnson and Scholes' assertion as merely fulfilling the requirements on the Environmental Law does not mean that a company has contributed to CSR. According to the Company Act, CSR is aimed to increase quality of life and environment. ${ }^{32}$ When a company follows Environment Act, it has simply fulfilled its environmental obligation which is aimed to protect the livelihood, health, and safety of the people as well as to prevent environmental pollution and/or damage. ${ }^{33}$ Such conduct does not contribute added value to people's life, neither does it fulfill the aim of CSR as set by the Company Act, i.e. to increase people's quality of life and the environment's.

\section{b. Redundancy}

Indonesian Company Act renders CSR mandatory, but its law and regulations do not stipulate a clear sanction to those who fail to fulfill such requirement. Judges in the Constitutional Court direct us to other sectoral law which has clearer stipulation on the obligation which has to be performed by the company, including the consequences if it fail to do so. It can be best understood that the obligation and sanction are not contained in the Company Act and its implementing regulation. Instead, it is contained in other laws and regulations. Question may arise out of this condition as the stipulation of mandatory CSR in the Company Act is

Johnson and Scholes, 2002, Exploring Corporate Strategy, Pearson Education, Harlow, p. 247.

Busyra Azheri, 2011, Corporate Social Responsibility: dari Voluntary menjadi Mandatory, Rajawali Pers, Jakarta, p. 273.

Art. 1(3) of Act No. 40 of 2007 regarding Limited Liability Company (State Gazette of The Republic of Indonesia Year 2007 Number 106, Supplement to State Gazette of The Republic of Indonesia Number 4756).

33 Art. 3 of Law No. 32 of 2009 on the Protection and Management of the Environment stipulates the aim of such Act, namely a) protecting the territory of Indonesia from environmental pollution and/or damage; b) assuring human safety, health, and life; c) assuring the continuation of environmental functions; d) preserving the conservation of environmental functions; e) achieving environmental harmony, synchronization and balance; f) assuring the fulfillment of justice for the present and future generations; g) assuring the fulfillment and protection of right to the environment as part of human rights; h) controlling the utilization of natural resources wisely; i) achieving sustainable development; and j) anticipating global environmental issues. 
redundant. Supposed that the stipulation on mandatory CSR in Art. 74 of Company Act is omitted, company will still perform the obligation as required by other sectoral laws

\section{CSR in Government Regulation}

Government Regulation No. 47 of 2012 on Limited Liability Company's Social and Environmental Responsibility stipulates implementing regulation concerning CSR planning, budgeting, and reporting. The stages of CSR process as regulated in the government regulation only set the things company have to do internally. For instance, the CSR activities shall be agreed by board of commissioners or general meeting of shareholders (GMS), unless regulated otherwise by the laws and regulations. ${ }^{34}$ In this implementing regulation, there is no such stipulation which regulates company's obligation to the government in terms of CSR planning and reporting. Neither does it regulate on government's duty on the supervision towards company in performing CSR.

One of the characteristics of welfare state is the works of executive power. ${ }^{35}$ Executive body, whose main task is to implement the laws and regulations, is supposed to bear authority over the implementation of CSR for limited liability company. However, such authority cannot be exercised until it is stipulated in the laws and regulations. The missing thing in either Company Act or its implementing regulation is government's authority towards company who implement CSR.

In the author's view, government is supposed to participate in supervising the implementation starting from pre-implementation, implementation, up to the post-implementation stages. In the preimplementation stage, government is supposed to provide guidelines on what the company should do with regards to its CSR. In the implementation stage, government is enocuraged to supervise the CSR program, whether it has been performed in accordance with the plan. In the post-implementation stage, it is better to have evaluation process by both government and company to weigh whether the CSR program has fulfilled government's target in order to fulfill people's needs. These stages show the role of executive power as one of the characteristics of welfare state in order to improve people's welfare.

In fact, within the Government Regulation on Company's CSR itself, there is no procedure stipulated to guide and to supervise the implementation of CSR program. It opens wider chance for the company to direct its CSR program as it wish. For instance, by contributing something to the people who might not need the contribution. In this regard, the purpose of public welfare cannot be achieved.

Similar to the stipulaton of Company Act, this government regulation also mentions that company will be given sanction if it does not conduct CSR. Such sanction will be stipulated by futher regulations. Still, there is no clearer stipulation on the sanction which will be imposed to the company who does not conduct CSR.

It can be seen that the laws and regulations applied in the national level are not sufficient to fulfill both the welfare state goal and public welfare. The laws and regulations are not sufficient to reach such goal because it is lack of planning, reporting, and sanction. This government regulation also shows a very minimum role of government authority over CSR implementation, the same government who wants CSR to be mandatory.

A less-strict laws and regulations, with no supervision and sanction clearly-stipulated, tends to create more conducive business atmosphere in Indonesia. CSR, which is mostly applied voluntarily, does not prevent the business player to establish limited liability company in Indonesia. Its drawback, especially related to the public welfare, is mistargeted CSR program due to the lack of supervision and sanction. The current government regulation only emphasizes on the internal relation

\footnotetext{
34 Art. 4(1) Government Regulation No. 47 of 2012 on Limited Liability Company's CSR (State Gazette of The Republic of Indonesia Year 2012 Number 89, Supplement to State Gazette of The Republic of Indonesia Number 5305).

35 A.F.K. Organski, 1969, The Stages of Political Development, Alfred A. Knopf, New York, pp. 167-168.
} 
within the limited liability company, and lack in focusing on the relationship between government and company.

\section{CSR in Regional Regulation}

In the provincial and municipal level, there have been several regional regulations on CSR. Such regulation can be found in Tasikmalaya Municipality, Tangerang Municipality, Siak Regency, East Kalimantan Province, and South Kalimantan Province. ${ }^{36}$ The regional regulations on CSR generally contain more guidance on what the company shall do in fulfilling its CSR obligation. It gives scope which has been adjusted by each region's needs and requirements.

In Tasikmalaya Municipality, for example, the CSR shall be focused on social, environment, health, education, cooperatives and micro business, as well as infrastructure. ${ }^{37}$ Similar scope is also given by Tangerang Municipality which requires company to participate in partnership with micro business and cooperatives, direct aid to the society, as well as capacity building. ${ }^{38}$ Most regional regulations require company to participate in increasing the people's quality of life through partnership with micro business and cooperatives. It also encourages the company to conduct various training in order to increase people's capacity in enterpreneurship. Besides, the regional regulations generally stipulate that company may give direct aid to the society in the form of grant, scholarship, subsidy, social aid, social service, and social protection. ${ }^{39}$

Not all regional regulations stipulate sanction to those who do not perform CSR. Siak, Tangerang, and East Kalimantan are among the regions which contain sanction if company fails to do its obligation. According to East Kalimantan Regional Regulation, administrative sanction will be imposed to the companies if it fails to fulfill its obligation. Such sanction can be in the form of written notification, business limitation, business suspension, business revocation, and other sanctions. ${ }^{40}$ In terms of sanction stipulation, East Kalimantan has a firm and clear wording which guarantee legal certainty towards the business actor. It is different from the sanction regulated by Tangerang Regional Regulation which states that the sanction is in accordance with the laws and regulations. ${ }^{41}$

Each region has a committee acting as control mechanism which control, supervise, and assess the application of company's CSR. ${ }^{42}$ Before conducting CSR, the company is obliged to consult with the committee on what kind of contribution shall be given to the people. ${ }^{43}$ This is a recommended procedure so that the company will have ideas on what the people needs; and in the end, the CSR implementation will be well-targeted. The

36 See Tasikmalaya Regional Regulation No. 4 of 2015 on CSR (Regional Gazette of Tasikmalaya Year 2015 Number 162, Supplement to Regional Gazette of Tasikmalaya Number 6). See Tangerang Regional Regulation No. 15 of 2011 on CSR (Regional Gazette of Tasikmalaya Year 2011 Number 15). See East Kalimantan Regional Regulation No. 3 of 2013 on CSR (Regional Gazette of East Kalimantan Year 2013 Number 3). South Kalimantan Regional Regulation No. 1 of 2014 on CSR (Regional Gazette of South Kalimantan Year 2014 Number 1 , Supplement to Regional Gazette of South Kalimantan Number 76).

37 Art. 15(1) Tasikmalaya Regional Regulation No. 4 of 2015 on Guideline to the Management of CSR as well as Partnership and Environment Building in Tasikmalaya.

38 Art. 15(1) Tangerang Regional Regulation No. 8 of 2012 on Limited Liability Company's CSR (Regional Gazette of Tangerang Year 2012 Number 8).

39 Art. 18 Tangerang Regional Regulation No. 8 of 2012 on Limited Liability Company’s CSR (Regional Gazette of Tangerang Year 2012 Number 8). A similar stipulation can also be fond in Art. 13 Siak Regional Regulation No. 1 of 2013 on Limited Liability Company's CSR (Regional Gazette of Tangerang Year 2013 Number 1, Supplement to Regional Gazette of Tasikmalaya Number 1). See Art. 14 East Kalimantan Regional Regulation No. 3 of 2013 on CSR (Regional Gazette of East Kalimantan Year 2013 Number 3).

40 Art. 27 East Kalimantan Regional Regulation No. 3 of 2013 regarding Corporate Social and Environment Responsibility (Regional Gazette of East Kalimantan Year 2013 Number 3).

41 Art. 23 Tangerang Regional Regulation No. 8 of 2012 on Limited Liability Company's CSR (Regional Gazette of Tangerang Year 2012 Number 8).

42 Art. 10 Tasikmalaya Regional Regulation No. 4 of 2015 on CSR (Regional Gazette of Tasikmalaya Year 2015 Number 162, Supplement to Regional Gazette of Tasikmalaya Number 6). Art. 19 East Kalimantan Regional Regulation No.3 of 2013 regarding Corporate Social and Environment Responsibility (Regional Gazette of East Kalimantan Year 2013 Number 3). Art. 11 of South Kalimantan Regional Regulation No. 1 of 2014 on CSR (Regional Gazette of South Kalimantan Year 2014 Number 1, Supplement to Regional Gazette of South Kalimantan Number 76).

43 Art. 11 of South Kalimantan Regional Regulation No. 1 of 2014 on CSR (Regional Gazette of Tasikmalaya Year 2014 Number 1, Supplement to Regional Gazette of Tasikmalaya Number 76). 
committee's task does not stop there. It shall also supervise the CSR implementation on whether the company has performed the designated conduct. If the committee finds violation, it shall report such finding to the regional government. In this way, the CSR implementation is well-supervised and its result can be enjoyed by the society.

\section{Behind The Mandatory CSR in Company Act}

This article is trying to point out the reason why Company Act obliges mandatory CSR for the company having business in and/or related to natural resources. The analysis provided is based on system approach which sees component of the system as a unity and State philosophical background as contained in Pancasila. Through such analysis, this article tries to elaborate the relation between the utilization and/or capability of natural resources with the mandatory CSR.

A similar research which considers mandatory CSR necessary was conducted by Busyra Azheri. $\mathrm{He}$ asserts that within the context of Indonesia, legislating mandatory CSR is important due to several reasons, namely: ${ }^{44}$

1) Most companies are still selfish in conducting business as they exclude society from their attention. Towards this view, the author sees that currently business entities start to realize that their operation depends on people, especially those who live in the vicinity of the company. Therefore, company does not exclude the society. Instead, they contribute something to the society in order to legitimate their existence in a particular place. In some extent, the author seconds Azheri's assertion that companies tend to be selfish because even though they have conducted CSR program, they do not really consider the people's interests. Instead, they use CSR as a tool of marketing.
2) Most companies have not realized that their existence depends on the environment where they perform business. The author supports this assertion since company has tendency to gain as much profit as it can. Allocating money for social and environmental contribution will highly likely cost the company more, and it will reduce the company's profit. As a result, company tries to maximize production while neglecting the fact that they have to participate in protecting the environment.

3) A weak legal culture in the business sector as corruption happens everywhere. Azheri asserts that it happens due to the weak legal enforcement. Towards this matter, the author seconds Azheri's opinion as the legal enforcement on the implementation of CSR program is still very limited. In the author's view, a weak legal enforcement is also caused by the less-firm law. As mentioned in the previous part of this chapter, the legislation on CSR does not provide a clear enforcement mechanism as well as sanction.

4) State's rights to control. The author's view on State's right to control will be explained in the next part of this subchapter.

The author basically seconds Azheri's assertion on why CSR needs to be mandatory. However, this article presents some more views on legitimating mandatory CSR in Indonesia, as the following:

\section{a. System Approach and Welfare State \\ System theory was firstly introduced by Ludwig von Bertalanffy on what he called Allgemeine Systemlehre in the first half of the $20^{\text {th }}$ century. ${ }^{45}$ It attempts to view the world in terms of irreducibly integrated system. ${ }^{46}$}

Busyra Azheri, Op. cit., p. 132

5 Alexander Laszlo and Stanley Krippner, "System Theories: Their Origins, Foundations, and Development", in J.S. Jordan, 1998, System Theories and A Priori Aspect of Perception, Elsevier Science, Amsterdam, pp. 47-74.

46 Ibid. 
The system approach focuses attention on the whole, as well as on the complex interrelationships among its constituent parts. ${ }^{47}$ Within this theory, every aspect is not seen as an alternative, but a complement to the specialized way. It is more all-embracing and comprehensive, incorporating the specialized perspective as one aspect of a general conception. ${ }^{48}$

From the above-mentioned description, it can be understood that unity is one of the fundamental principles acknowledged by system theory. It is required in order to maintain sustainability of collective life. Further, unity is considered as the product of optimal interaction among the components in a social system. ${ }^{49}$ When linked to the context of Corporate Social Responsibility, unity can be reached through the repeated interactions among company, people, and government ${ }^{50}$ in order to make the system work and function normally.

Good quality interaction among the components will stimulate full participation of the components in optimising their role and function proportionally, in order to maintain the unity as their identity. Such interaction requires a balance or equality. In legal context, such balance can be interpreted as justice. ${ }^{51}$ In other words, justice shall be dedicated to maintain unity which guarantees the sustainability of collective life as its ultimate goal. Therefore, the policy which ignore and destroy unity and sustainability shall, at the maximum efforts, be prevented and avoided.
The system approach itself cannot justify the existence of mandatory CSR in Indonesia as the system theory does not require the role of authority in order to regulate the interactions among components within the system. Under a well-maintained condition, the role of authority in establishing mandatory CSR is not necessary because the company, through its interaction with the people, has contributed something considered as CSR. However, in a developing country like Indonesia, there is a tendency that capital (business sector) wins over people. ${ }^{52}$ It triggers government, who bear the responsibility over its people, to play its role by laws and regulations. This is also one of the characteristics of welfare state, where government protects its people from the capital.

Regulation is required for the interaction among components within the system in order to create justice. Government, through Company Act, requires company to perform CSR. This is to shift subject-object paradigm into subject-subject paradigm under the unity principle of the system theory. Under this principle, the relationship among components in the system should strengthen each other in the form of give and take relationship ${ }^{53}$ for the sake of maintaining sustainability of the system. Within the context of CSR, the company which has taken natural resources from the society, shall give something back to it in order to maintain balance and sustainability.

\section{Ibid.}

Ibid.

49 Hayyan U1 Haq, "Strengthening the Philosophical and Axiological Legal Framework of CSR in Indonesia", in Tineke Elizabeth Lambooy, et al., 2013, CSR in Indonesia: Legislative Developments and Case Studies, Konstitusi Press, Jakarta, pp. 3-39.

50 This is only a simplified example of interactions in the CSR framework. In fact, the interaction as meant by system theory is not only limited to company, people, and government. It shall be extended to the natural resources and the environment as well.

51 Hayyan Ul Haq, Loc.cit.

52 This is explained in the Organski's Stages of Political Development in which developing countries need a lot of capital for it to develop, as a result the people often sacrificed over capital.

53 Hayyan Ul Haq, Loc. cit. 


\section{b. Social Justice in Pancasila}

Pancasila, the five principles, as the ideology of the state and the life philosophy of Indonesian society is the source of Indonesian positive law. It is considered as the embodiment of basic principles of an independent Indonesian state. As a consequence, the laws and regulations shall be in line with Pancasila. The fifth principle contains social justice for all Indonesian citizen. The inference of this principle can be found in the Indonesian 1945 Constitution Article 33 on the national economics.

The stipulation within 1945 Constitution emphasizes more on people's welfare. It states that 'land, water, and natural resources beneath it are controlled by the State and utilized for the maximum welfare of the people. ${ }^{54}$ It shows that the State has the right to control the utilization and exploitation of such natural resources. Various interpretation arises towards the terminology of state's rights to control. Moh. Hatta asserts that State's right to control does not suggest State's role as businessman over its own natural resources. Instead, it refers to State's authority in making regulation for the sake of economic development. Such regulation shall also prohibit arbitrariness towards the people. ${ }^{55}$ Further this interpretation is elaborated in three main points, namely: i) government's task is to supervise and regulate based on the people's interests; ii) government role shall be increased along with the increase of company's size and the number of people who depends upon it; and iii) land shall be placed under state's authority. ${ }^{56}$

The concept of State's right to control, when related to the concept of welfare state, places State as the regulator and guarantor of people's welfare. This function cannot be separated from one another, meaning that when State releases natural resources business to private entity (company), it has to create a specific laws and regulations so that the business is still placed under the State's control for the sake of people's welfare. It means that when there is a company who wants to exploit natural resources, it becomes subject to the State's control. Therefore, with the State's sovereignty and authority, it can establish laws and regulations over the company's obligation with purpose to control the utilization and exploitation of natural resources. This includes company's obligation if its business is in the field of and/ or related to natural resources.

State's rights to control has also become the reason behind mandatory CSR according to Azheri. In his dissertation, he asserts that State's rights to control is necessary in order to create a sustainable development. ${ }^{57}$ Such notion is based upon Article 33 of Indonesian 1945 Constitution. He basically asserts that the mining company is working on nonrenewable natural resources. Therefore, to guarantee the idea of social justice and public welfare, mandatory CSR shall be applicable to the mining companies. ${ }^{58}$

Mandatory CSR is in line with the philosophy of the State as it is needed in order to exercise government's control over the natural resources. The grandest purpose of this mandatory CSR is to create social justice among Indonesian people. If this philosophy is related to the above-elaborated system theory, justice shall maintain unity among

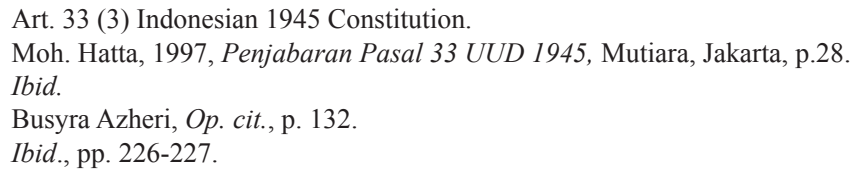


government, natural resources, company, and the people in order to guarantee sustainability of the collective life.

\section{c. Company's Focus in Conducting CSR}

Company's main focus is to generate as much profit as it can for itself and its own shareholders. People's welfare has rarely, or never, been their ultimate focus in conducting business. Instead, the companies have other motivations which become bases to their CSR, among others to promote itself in the competitive marketplace, to prove that they have actually done something good to the society, as well as to legitimize its own place among the people.

Other companies might have hidden itself behind the 'CSR mask's; they contribute something to the society for the purpose other than goodness and welfare to the people. It happens when the mandatory CSR is in force. In a hypothetical condition, supposed that the CSR is left voluntary, there are two possibilities: i) the company still performs CSR to legitimize its own place within the society or ii) the company does not conduct CSR as it is not required by the government.

Noticing that business entity in Indonesia rarely puts its aim on people's well being, the author is in the view that mandatory CSR shall be in force in order to enhance people's welfare. Mandatory CSR might not be able to guarantee such welfare, but at least there is something a company shall contribute. It is, apparently, better than exploiting natural resources without any payback to the society.

\section{Conclusion}

Mandatory CSR as regulated by Company
Act and Government Regulation give company space to contribute to the society without any particular guideline and control mechanism by the government. Only in the regional level are the guideline, control mechanism, and sanction stipulated clearly. Leaving more specific details such as scope and supervisory function to the regional authority shows that the laws and regulations on CSR are generally quite flexible to accommodate business actors. Moreover, it also take into account the regional interests which shall be adjusted by its own regional regulation. Unfortunately, there are still many regions have not had regulations on CSR. As a consequence, company which operates on the region with no regional regulations on CSR is only bound by the Company Act, its implementing regulations, and other secotral law. Therefore it is quite acceptable that such company does not have a clear target on and scope of CSR implementation.

This article finds three reasons why CSR shall be mandatory for the company having business in the filed of and/or related to natural resources. Firstly, the system approach requires participation of all components within the system in order to create sustainable development. This interaction, however, cannot perform well without government interference which tries to protect people from the capital. In this regard, mandatory CSR is required to keep the system works, to create justice, as well as to reach sustainable development. Secondly, social justice principle in Pancasila has inferred to the State's control over its natural resources. It gives the State authority to regulate mandatory CSR in order to create social justice for Indonesian citizen. Thirdly, since the main goal of business player is to create profit, mandatory CSR is needed to remind company that it shall also contribute to the people's welfare to increase their quality of life and to create sustainable development. 


\section{REFERENCES}

\section{A. Books}

Azheri, Busyra, 2011, Corporate Social Responsibility: dari Voluntary menjadi Mandatory, Rajawali Pers, Jakarta.

Hatta, Moh., 1997, Penjabaran Pasal 33 UUD 1945, Mutiara, Jakarta.

Johnson and Scholes, 2002, Exploring Corporate Strategy, Pearson Education, Harlow.

Organski, A.F.K., 1969, The Stages of Political Development, Alfred A. Knopf, New York.

World Commission on Environmental and Development, 1987, Our Common Future, Oxford University Press, Oxford.

\section{B. Anthologies}

Laszlo, Alexander and Krippner, Stanley, "System Theories: Their Origins, Foundations, and Development", in J.S. Jordan, 1998, System Theories and A Priori Aspect of Perception, Elsevier Science, Amsterdam.

Haq, Hayyan U1, "Strengthening the Philosophical and Axiological Legal Framework of CSR in Indonesia", in Tineke Elizabeth Lambooy, et al., 2013, CSR in Indonesia: Legislative Developments and Case Studies, Konstitusi Press, Jakarta.

\section{Journal Articles}

Thomas Gladwin and James Kennelly, "Shifting Paradigm for Sustainable Development: Implications for Management Theory and Research", Academy of Management Review, Vol. 20, No. 4, 1995.

Sabela.Gayo,." Mandatory.and.Voluntary. Corporate.Social.Responsibility.Policy. Debates.in Indonesia”, ICIRD, June, 2012.

Thomas A. J. McGinn, "The Expressive Function of Law and Lex Imperfecta”, Roman Legal Tradition, Vol. 11, 2015.

\section{Internet Articles}

United Nations Research Institute for Social
Development, "Research and Policy Brief 1 Corporate Social Responsibility and Business Regulation", http://www.unrisd. org/80256B3C005BCCF9/httpNetITFrame PDF? ReadForm\&parentunid $=F 862 A 71428$ FAC633C1256E9B002F1021\&parentdocty pe $=$ brief\&netitpath $=80256 B 3 C 005 B C C F 9 /$ (httpAuxPages)/F862A71428FAC633C1256 E9B002F1021/\$file/RPB1e.pdf, accessed on 2 Februari 2016.

The American Heritage Dictionary, "What is Environment",

https://www.ahdictionary.com/word/search. html $? q=$ environment, accessed on 2 February 2016.

\section{E. Research Reports}

European.Sustainable.Development.Network, 2011, Focus CSR: The New Communication of the EU Commission on CSR and National CSR Strategies and Action Plans, ESDN Quarterly Report, European.Sustainable. Development.Network, Viena.

Laurensia Andrini, 2016, Corporate Social Responsibility for Limited Liability Company in Indonesia as a Mechanism to Improve People's Welfare, Graduate Thesis, Faculty of Law Universitas Gadjah Mada, Yogyakarta.

\section{F. Regulations}

Indonesian 1945 Constitution.

Act No. 40 of 2007 regarding Limited Liability Company ( State Gazette of The Republic of Indonesia Year 2007 Number 106, Supplement to State Gazette of The Republic of Indonesia Number 4756.

Act No. 32 of 2009 on the Protection and Management of Environment (State Gazette of The Republic of Indonesia Year 2009 Number 140, Supplement to State Gazette of The Republic of Indonesia Number 5059).

Government Regulation No. 27 of 2012 on 
Environmental Permit (State Gazette of The Republic of Indonesia Year 2012 Number 48, Supplement to State Gazette of The Republic of Indonesia Number 5285).

Tangerang Regional Regulation No. 15 of 2011 on CSR (Regional Gazette of Tasikmalaya Year 2011 Number 15).

East Kalimantan Regional Regulation No. 3 of 2013 on CSR (Regional Gazette of East Kalimantan Year 2013 Number 3).

South Kalimantan Regional Regulation No. 1 of 2014 on CSR (Regional Gazette of
South Kalimantan Year 2014 Number 1, Supplement to Regional Gazette of South Kalimantan Number 76).

Tasikmalaya Regional Regulation No. 4 of 2015 on CSR (Regional Gazette of Tasikmalaya Year 2015 Number 162, Supplement to Regional Gazette of Tasikmalaya Number 6).

\section{G. Court Decision}

Constitutional Court Decision No. 53/PUU$\mathrm{VI} / 2008$. 